\title{
Seasonal changes in testicular contents and plasma concentrations of androgens in the desert gerbil (Gerbillus gerbillus)
}

\author{
F. Khammar and R. Brudieux* \\ Laboratoire d'Endocrinologie et Ecophysiologie animale, Unité de Recherches sur les Zones Arides \\ (U.S.T.H.B.), B.P. 119, rue Danton, Alger, Algérie
}

\begin{abstract}
Summary. Gerbils were caught in the Béni-Abbès area (Algeria). Testicular endocrine activity was highest in spring (testicular wt $298 \pm 10 \mathrm{mg}$; seminal vesicle wt $603 \pm 62 \mathrm{mg}$; testicular testosterone and androstenedione content $9.2 \pm 1.7$ and $0.5 \pm 0.1 \mathrm{ng} /$ testis; plasma testosterone $832 \pm 200 \mathrm{pg} / \mathrm{ml}$ ). Values decreased in summer, were lowest in late summer and in autumn $(84 \pm 17 \mathrm{mg} ; 40 \pm 14 \mathrm{mg}$; $0.20 \pm 0.06$ and $0.02 \pm 0.01 \mathrm{ng} /$ testis; $228 \pm 54 \mathrm{pg} / \mathrm{ml}$, respectively) and increased again in winter (December-January).

The onset of testicular endocrine activity was concomitant with the lowest temperatures and the shortest photoperiod; it increased when temperatures and daylength were increasing and began to decline when temperatures and photoperiod were still maximal. These seasonal changes in the endocrine activity of the testis of the gerbil differ from those of the sand rat inhabiting the same area.
\end{abstract}

\section{Introduction}

Studies of seasonal reproductive activities of desert mammals are not currently found in the literature. Nevertheless, there are a few reports from environmental physiologists and ecologists in various desert countries around the world (Charnot, 1964; Mauer \& Bradley, 1965; Sapozenikhov, 1965; Reichman \& Van de Graaf, 1973; Cheniti-Lamine, 1974; Happold, 1975; Misonne, 1975; Naumov \& Lobachev, 1975; Prakash, 1975; Smith \& Jorgensen, 1975; Gombe \& Oduor-Okelo, 1977; Singh \& Bharadwaj, 1978; Bedrak et al., 1983; Friedlander et al., 1984; Osman \& Ploën, 1986).

We have reported seasonal changes in the endocrine function of the testis in the sand rat (Psammomys obesus), a desert rodent inhabiting underground burrows on briny alluvial platforms of the Algerian Sahara (Khammar \& Brudieux, 1984). We have also suggested, from weight data, that the desert gerbil (Gerbillus gerbillus) exhibits seasonal reproductive activity in the field (Khammar et al., 1975; Amirat et al., 1977).

In the present work, we have studied seasonal changes of endocrine function of the desert gerbil (Gerbillus gerbillus), measuring testicular and seminal vesicle weights, annual variations in testicular content of testosterone and androstenedione and plasma concentrations of testosterone.

\section{Materials and Methods}

Animals. Gerbils (Gerbillus gerbillus) were obtained from the Béni-Abbès area (Wilaya of Béchar, Algeria; $30^{\circ} 7^{\prime} \mathrm{N}$, $2^{\circ} 10^{\prime} \mathrm{W}$ ) in the Sahara desert. The gerbil is a nocturnal, insectivorous and gramnivorous rodent. Adult males were livetrapped in the field, near the fixed sand hill in the oasis. The adult condition was checked according to the body

\footnotetext{
*Present address: Laboratoire d'Endocrinologie Comparée, U.E.R. de Biologie, Université de Bordeaux, I, avenue des
} Facultés, 33405 Talence Cédex, France. 
weight, the state of the genital apparatus (during the breeding period) and the wearing surface of the molars. These adult criteria were defined in a group of gerbils, trapped in November-December, which could be considered as adults because no pregnant females were obtained from July. Seasonal changes in body weights (higher in spring and lower in September) probably resulted directly from annual variations in environmental conditions, i.e. in summer there could be delayed development of body weight.

Between December 1978 and January 1980 (26-31 December 1978; 24 February-2 March 1979; 10-18 April 1979; 5-25 June 1979; 15-18 September 1979; 10-22 October 1979; 28 November-6 December 1979; 27 December 1979-4 January 1980), 77 gerbils were caught for study. Immediately after trapping, they were kept for about $3 \mathrm{~h}$ in the laboratory and then killed by decapitation, always in the late morning. Blood from the neck was collected on calcium heparinate and immediately centrifuged. Seminal vesicles and testes were quickly removed and weighed. The left testis and plasma were immediately frozen and carried in liquid nitrogen to Alger, where they were stored at $-25^{\circ} \mathrm{C}$ until assayed.

Hormone assays. Testicular testosterone and androstenedione contents were measured by radioimmunoassays (RIA) according to a technique similar to that previously described by Darbeida \& Brudieux (1980) and slightly modified and validated by Khammar \& Brudieux (1984). The results, corrected for recovery, dilutions and water blank, were expressed as ng/testis for both hormones. The sensitivities of the assays were $7 \cdot 3 \mathrm{pg}$ testosterone/tube and $10.2 \mathrm{pg}$ androstenedione/tube and the within- and between-assay variances were $<10 \%$ for testosterone and 12.2 and $10 \cdot 2 \%$ for androstenedione.

Plasma testosterone concentrations were measured by the same technique; but, because of the very low plasma values in gerbil, the purification step on Celite columns was suppressed. However, the method used was sensitive (after logit-log transformation: standard curve was linear between 5 and $500 \mathrm{pg}$; blank value was $3.5 \mathrm{pg} / \mathrm{tube}$; mean recoveries were $77.2 \pm 2.0 \%$ ), precise (within-assay variance $3.0 \%$; between-assay variance $10.5 \%$ ); and specific (with the testosterone antiserum used (Institut Pasteur, Paris, France), only dihydrotestosterone interfered significantly (36\% cross-reaction) and in the gerbil, plasma dihydrotestosterone concentration is $<10 \%$ that of testosterone).

Statistical analysis. Means and standard errors were calculated and the significance of the difference was determined by Student's $t$ test.

\section{Results}

\section{Testicular and seminal vesicle weights}

Data reported in Table 1 show that the testicular and seminal vesicles weights exhibited similar marked seasonal variations. The heaviest testes and seminal vesicles occurred in April; weights declined in late spring and early summer, and reached a minimum in autumn $(-71.8 \%, P<0.001$, for the testis and $-93.4 \%, P<0.001$ for seminal vesicles, between April and October). Testicular and seminal vesicle weights then increased significantly $(+76.2 \%, P<0.02$ for the testis; $+435.0 \%, P<0.001$ for seminal vesicles) in early winter (December-January).

Table 1. Seasonal changes in body weight and testicular and seminal vesicle weights in adult male gerbils

\begin{tabular}{lcccc}
\hline Time of sample & $\begin{array}{c}\text { No. of } \\
\text { animals }\end{array}$ & $\begin{array}{c}\text { Body weight } \\
(\mathrm{g})\end{array}$ & $\begin{array}{c}\text { Testicular weight } \\
\text { (left testis) } \\
(\mathrm{mg})\end{array}$ & $\begin{array}{c}\text { Seminal } \\
\text { vesicle weight } \\
(\mathrm{mg})\end{array}$ \\
\hline 26-31 Dec. 1978 & 6 & $32 \pm 3$ & $191 \pm 37$ & $252 \pm 90$ \\
24 Feb.-2 Mar. 1979 & 15 & $40 \pm 2$ & $285 \pm 14$ & $542 \pm 55$ \\
10-18 Apr. 1979 & 12 & $43 \pm 1$ & $298 \pm 10$ & $603 \pm 62$ \\
5-25 Jun. 1979 & 11 & $39 \pm 3$ & $222 \pm 38$ & $332 \pm 65$ \\
15-18 Sept. 1979 & 7 & $27 \pm 2$ & $96 \pm 22$ & $55 \pm 25$ \\
10-22 Oct. 1979 & 14 & $35 \pm 1$ & $84 \pm 17$ & $74 \pm 26$ \\
28 Nov.-6 Dec. 1979 & 10 & $33 \pm 3$ & $148 \pm 22$ & $40 \pm 14$ \\
27 Dec. 1979-4 Jan. 1980 & 11 & $33 \pm 2$ & $214 \pm 15$ & $214 \pm 22$ \\
\hline
\end{tabular}

Values are means \pm s.e.m. 


\section{Testicular contents of testosterone and androstenedione}

The mean hormone changes in the testis are shown in Fig. 1(a). Throughout the year, values ranged between 0.20 and $9.25 \mathrm{ng}$ for testosterone and between 0.03 and $0.50 \mathrm{ng}$ for androstenedione; both hormones exhibited similar statistically significant seasonal changes.

Maxima were in April; a steep decline occurred as early as in June $(-57.0 \%, P<0.01$ for testosterone; $-78.4 \%, P<0.01$ for androstenedione) and the lowest values were in autumn. In October, mean contents of the testis were $0.20 \mathrm{ng}$ for testosterone and $0.2 \mathrm{ng}$ for androstenedione in the 10 animals in which values were low, but 2 gerbils still had a high testicular content of androgens $(6.5 \mathrm{ng}$ for testosterone, and $0.15 \mathrm{ng}$ for androstenedione $)$. A significant $(P<0 \cdot 01)$ increase (testosterone $+450 \%$; androstenedione $+150 \%$ ) occurred at the beginning of December and continued in January (testosterone $+1610 \%, P<0.001$; androstenedione $+700 \%, P<0.01$ ). When values were expressed as $\mathrm{ng} / 100 \mathrm{mg}$ testis, the profile was essentially the same.

\section{Plasma concentrations of testosterone}

Mean values (Fig. Ib) ranged from $228.5 \mathrm{pg} / \mathrm{ml}$ in autumn to $832.4 \mathrm{pg} / \mathrm{ml}$ in spring. They exhibited seasonal variations, which paralleled those observed for testicular androgen content, but the changes were much less and most were not significant. The maximum was in April 1979, a
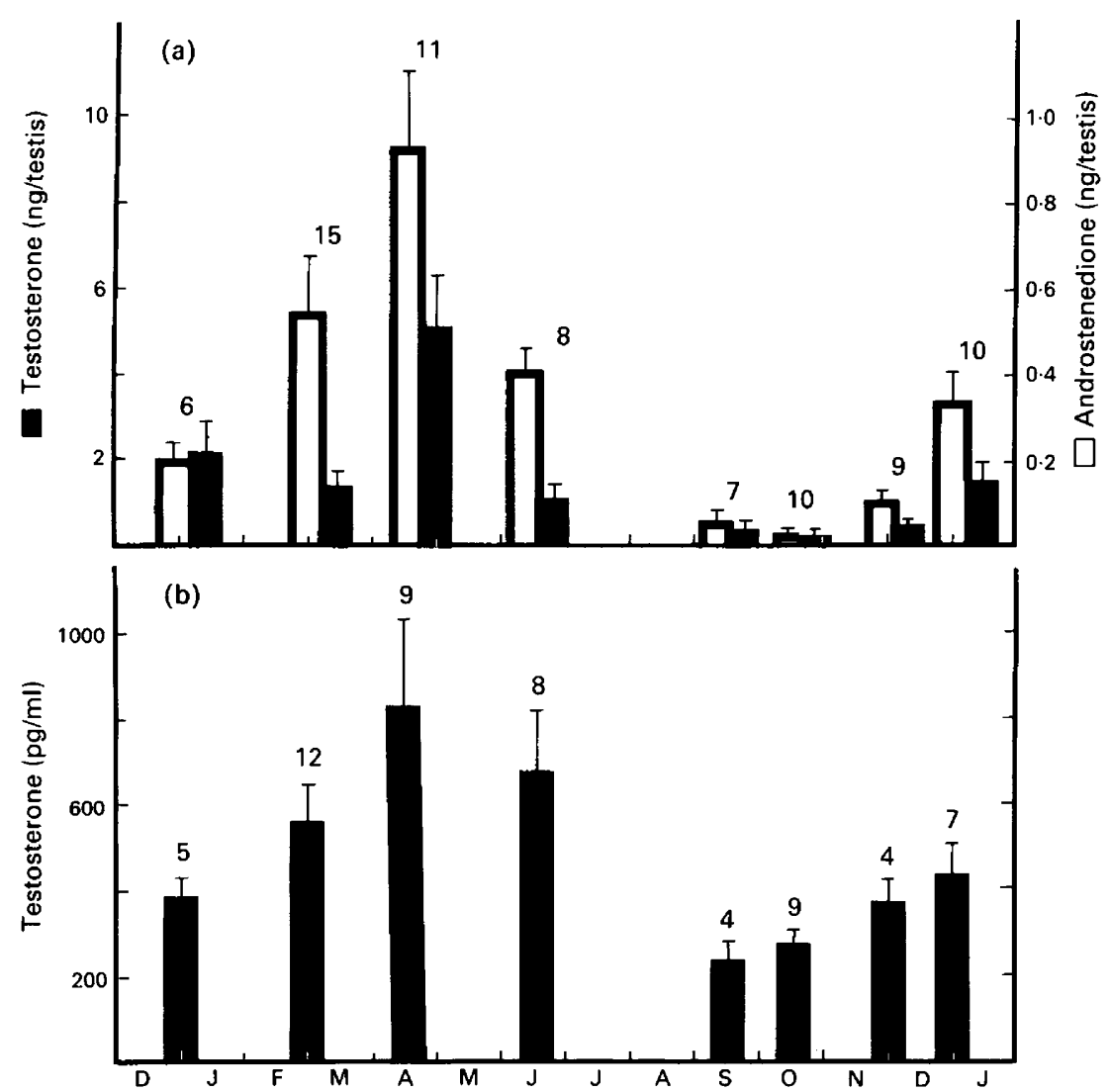

Fig. 1. Seasonal changes in (a) testicular contents of testosterone and androstenedione and (b) plasma testosterone in adult male gerbils. Values are means \pm s.e.m. for the number of animals indicated. 
modest decline occurred in June $(-18.2 \%, P<0.5)$ and continued to minimum values in autumn $(-67.2 \%, P<0.01)$. Concentrations increased again in December and January $(+58.2 \%$, $P<0.02)$. There were some individual variations, e.g. 1 gerbil had a very low plasma concentration of testosterone in June, and 2 gerbils still had elevated testosterone values in October.

\section{Discussion}

Testicular contents of androgens in the gerbil (Gerbillus gerbillus) were similar to those observed in the sand rat (Psammomys obesus), a diurnal rodent inhabiting the same area (Khammar \& Brudieux, 1984); they were lower than those of laboratory rodents (for references see Khammar \& Brudieux, 1984).

Likewise, plasma concentrations of testosterone in the gerbil were similar to those of the sand rat. They are approximately $10 \%$ of those reported for other mammals, particularly for laboratory rodents (for references, see Khammar \& Brudieux, 1984). The very low plasma concentrations of androgens are probably a feature of desert mammals such as camels (Gombe \& Oduor-Okelo, 1977; Bedrak et al., 1983) and desert donkeys (Gombe \& Oduor-Okelo, 1977). In the gerbil, the lower plasma concentrations of testosterone are probably not the result of a higher metabolic clearance rate, since in the sand rat (Khammar \& Brudieux, 1984) this value was comparable to that obtained in other rodents (for references, see Khammar \& Brudieux, 1984). Lower testicular endocrine activity has been correlated, in camels, to a reduced activity of steroidogenic enzymes associated with androgen biosynthesis (Bedrak et al., 1983).

However, all the values investigated in the present study (testicular weight, seminal vesicle weight, testicular contents of testosterone and androstenedione and plasma concentration of testosterone) exhibited marked similar annual changes. These results clearly demonstrated the occurrence of a seasonal cycle in the endocrine activity of the testis of the wild-caught gerbil in the Béni-Abbès area. It was highest in spring (April), decreased in summer and was lowest in late summer and in autumn; the onset was in winter (December-January). The present results for 19781980 confirmed our previous observations in 1974 (Amirat et al., 1977).

At present we cannot explain the determining factors of these seasonal variations. It is unlikely that changes in plasma concentrations of testosterone, particularly the summer reduction, are the result of an increased metabolic clearance rate, because, in the sand rat, similar seasonal changes paralleled those of the endocrine activity of the testis (Khammar \& Brudieux, 1984). Annual variations in the linkage capacity of the specific steroid binding protein should be studied: indeed, Gustafson \& Damassa (1985) have shown seasonal changes in sex steroid-binding protein in the bat. The paradoxical situation in this desert rodent of a large development of the genital apparatus especially of the seminal vesicles, and low plasma concentration of testosterone poses several questions. Are sexual effectors more sensitive to testosterone than in other species? Is there lower linkage to plasma proteins resulting in a high proportion of free testosterone? Does the testis secrete androgenic steroids other than testosterone?

Further studies need to be undertaken to determine whether changes in testicular activity result from annual variations of the hypothalamo-pituitary gonadotrophin activity and/or the response of the testis itself to gonadotrophins. The influence of environmental factors such as temperature, nutrition and photoperiod also need to be examined. In gerbils, the onset of testicular activity was concomitant both with the lowest temperatures and the shortest photoperiod, increasing when temperatures and daylength were increasing. The beginning of regression coincided with the hardest conditions, when temperatures and photoperiod were maximal (Fig. 2). At the same period and in the same region, the sand rat exhibited a different annual cycle of testicular endocrine activity. The resumption of testicular endocrine function of the sand rat was concomitant both with the highest temperatures and the start of increasing daylength; its regression occurred when temperatures and photoperiod were increasing. However, these species have different behaviour 


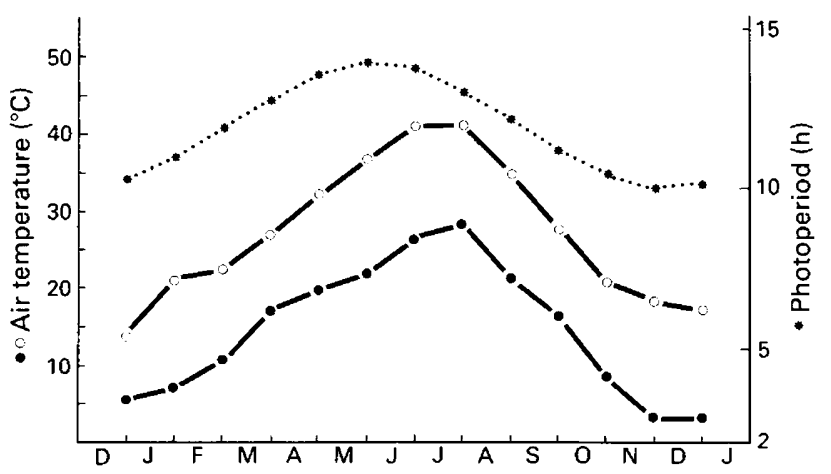

Fig. 2. Annual variations in air temperature ( $\bigcirc$ maximum; $\bigcirc$ minimum) and photoperiod $(\star)$ in the Béni-Abbès area $\left(30^{\circ} 07^{\prime} \mathrm{N} ; 2^{\circ} 10^{\prime} \mathrm{W}\right)$ between January 1979 and January 1980.

and food habits: the gerbil is a nocturnal, insectivorous and gramnivorous animal, while the sand rat is a diurnal herbivorous rodent. Further comparative investigations of these two species of desert rodents should contribute to our understanding of the causes of the seasonal variations in the endocrine activity of the testis.

\section{References}

Amirat, Z., Khammar, F. \& Brudieux, R. (1977) Variations saisonnières comparées de l'activité sexuelle (données pondérales) chez deux espèces de Rongeurs (Psammomys obesus et Gerbillus gerbillus) du Sahara occidental algérien. Mammalia 41, 341-356.

Bedrak, E., Rosentrauch, A., Kafka, M. \& Friedlander, M. (1983) Testicular steroidogenesis in the camel (Camelus dromedarius) during the mating and the nonmating seasons. Gen. comp. Endocr. 52, 255-264.

Charnot, Y. (1964) Cycle testiculaire du Dromadaire. Bull. Soc. Sci. nat. Phys. Maroc 44, 38-45.

Cheniti-Lamine, T. (1974) Cycle saisonnier de reproduction chez un rongeur de Tunisie, Meriones shawi. J. Physiol., Paris 69, 190, Abstr.

Darbeida, H. \& Brudieux, R. (1980) Seasonal variations in plasma testosterone and dihydrotestosterone levels and in metabolic rate of testosterone in rams in Algeria. J. Reprod. Fert. 59, 229-235.

Friedlander, M., Rosentrauch, A. \& Bedrak, E. (1984) Leydig cell differentiation during the reproductive cycle of the seasonal breeder Camelus dromedarius: an ultrastructural analysis. Gen. comp. Endocr. 55, 111.

Gombe, S. \& Oduor-Okelo, D. (1977) Effect of temperature and relative humidity on plasma and gonadal testosterone concentrations in camels (Camelus dromedarius). J. Reprod. Fert. 50, 107-108.

Gustafson, A.W. \& Damassa, D.A. (1985) Annual variations in plasma sex steroid-binding protein and testosterone concentrations in the adult male little brown bat. Relation to the asynchronous recrudescence of the testis and accessory reproductive organs. Biol. Reprod. 33, 1126-1137.

Happold, D.C.D. (1975) The ecology of rodents in the northern Sudan. In Rodents in Desert Environments, pp. 15 44. Eds I. Prakesh \& P. K. Ghosh. W. Junk, The Hague.

Khammar, F. \& Brudieux, R. (1984) Seasonal changes in testicular contents of testosterone and androstenedione and in the metabolic clearance rate of testosterone in the sand rat (Psammomys obesus). $J$. Reprod. Fert. 71, 235-241.

Khammar, F., Amirat, Z. \& Brudieux, R. (1975) Variations pondérales saisonnières de l'appareil reproducteur de la surrénale et du rein chez la Gerbille (Gerbillus gerbillus) du Sahara occidental algérien. Bull. Soc. Hist. nat. Afr. Nord, Alger 66, 63-88.

Mauer, R.A. \& Bradley, W.G. (1965) Reproduction and food habits in Merriam's kangaroo rat. Desert Res. Inst., Preprint Ser., 37, Univ. Nevada-Reno, 17pp.

Misonne, X. (1975) The rodents of the Iranian deserts. In Rodents in Desert Environments, pp. 47-58. Eds I. Prakash \& P. K. Ghosh. W. Junk, The Hague.

Naumov, N.P. \& Lobachev, U.S. (1975) Ecology of the desert rodents of the USSR. In Rodents in Desert Environments, pp. 565-590. Eds I. Prakash \& P. K. Ghosh. W. Junk, The Hague.

Osman, D.I. \& Plöen, L. (1986) Spermatogenesis in the camel (Camelus dromedarius). Anim. Reprod. Sci. 10, 23-36.

Prakash, I. (1975) The population ecology of the rodents of the Rajathan desert, India. In Rodents in Desert Environments, pp. 75-114. Eds I. Prakash \& P. K. Ghosh. W. Junk, The Hague.

Reichman, D.J. \& Van de Graaf, K.M. (1973) Seasonal activity and reproductive patterns of five species of Sonoran desert rodents. Am. Midl. Nat. 98, 118-126.

Sapozenikhov, J.F. (1965) Reproduction des mammifères 
dans le désert de sable de Karakoum. Zool. J., Zl. S.S.S.R. 44, 896-901.

Singh, U.B. \& Bharadwaj, M.B. (1978) Histological and histochemical studies on the testis of camel Camelus dromedarius during the various seasons and ages, part II. Acta anat. 101, 280-288.
Smith, H.D. \& Jorgensen, C.D. (1975) Reproductive biology of North American desert rodents. In Rodents in Desert Environments, pp. 305-328. Eds I. Prakash \& P. K. Ghosh. W. Junk, The Hague.

Received 25 November 1986 